\title{
チーム・アイデンティフィケーションと地域愛着間の媒介変数に関する考察
}

菅 文 彦* 古川拓也* 舟橋弘 晃**
間 野 義 之** $^{* *}$

\section{Consideration of the Parameters of the Relationship between Team Identification and Place Attachment ${ }^{\dagger}$}

\author{
Fumihiko KAN*, Takuya FURUKAWA* , Hiroaki FUNAHASHI** \\ and Yoshiyuki MANO**
}

\begin{abstract}
Although a causal relationship has been suggested between Team Identification and Place Attachment, it may be necessary to verify the existence of the parameters between them. In this research, "The rise of Team Identification is accompanied by the rise in the evaluation of the social environment of the community, and leads to the rise of Place Attachment," was aimed at the hypothesis to be verified.

As a result of the two-way analysis of variance based on data from three longitudinal surveys, we determined that Team Identification ascending group significantly increased both Place Attachment and the bonds of the community as compared to the non-ascending group, and it was suggested that the evaluation of the social environment of the community rose in the ascending group. It can be said that the hypothesis was supported, considering the fact that "regional attachment influence structure" was confirmed in Imabari-City, the area of survey on this study.
\end{abstract}

Key words : Team Identification, Place Attachment, Social Impact

1. 緒言

2018年で設立から25年を迎えたJリーグは, その節目に「わたしたちは地域社会の一員であ るという考えのもと, 地域との関係性を大切に 生きてきました。 これからも, 街も人も元気に なる，成長する，そんな物語を生むきっかけに なれればと思っています」とうたっている ${ }^{1)}$. Jリーグやプロ野球，Bリーグなど地域を拠点
とするプロスポーツチームは，地域社会に有形 無形の様々な価值をもたらすとされる ${ }^{2)}$ 。 ホー ムタウンの自治体が，チームへの出資や施設利 用料の減免，広報協力など有形無形の支援を行 うことは，その証左であろう。

スポーツが地域に及ぼす効果は, (1)経済・産 業振興，(2)インフラ整備，(3)人材育成，(4)地域 間の交流促進, (5)地域アイデンティティ形成, (6)地域コミュニティ形成 ${ }^{3)}$ や， (1)社会資本の整

\footnotetext{
†原稿受付 2018年 6 月 12 日 原稿受諾 2018年 8 月 21 日

*大阪成蹊大学マネジメント学部 †533-0007 大阪府大阪市東淀川区相川 3-10-62

**早稲田大学スポーツ科学学術院 干202-0021 東京都西東京市東伏見 $3-4-1$

* Faculty of Management, Osaka Seikei University, 3-10-62, Aikawa, Higashiyodogawa-ku, Osaka, Osaka, Japan (533-0007)

** Faculty of Sport Science, Waseda University, 3-4-1, Higashifushimi, Nishitokyo, Tokyo, Japan (202-0021)
} 
備, (2)消費の誘発, (3)地域の連带性の向上, (4) 都市のイメージ向上 ${ }^{4)}$ などに整理され, 経済効 果と社会効果に大別されることが多い. 経済効 果に関しては, スポーツイベント開催やスポー ツ合宿・キャンプ受け入れ，プロスポーツ興行 等による効果額の推計が数多く行われ，Jクラ ブが地域に存在することによる経済効果も金額 算出されている ${ }^{5)}$.

社会効果も, 概念や定義の曖昧さや効果測 定の困難さなどの課題を抱えながらも, 実証 研究や尺度開発の試みが近年進んでいる。例 えばCrompton ${ }^{6)}$ は, MLBのスタジアム建設 の便益として(1)直接的な経済効果, (2)地域コ ミュニティの活性化, (3)地域イメージの向上, (4)他の地域開発の誘因, (5)心理的所得（社会 的な結束感, 地域の誇りなど）からなるとし, “Beyond Economic Impact” と文献タイトルに あるように, 経済的効果以外の要素に着目した。 Taks ${ }^{7)}$ は地域で開催されるノン・メガスポー ツイベントにおいて, 地域アイデンティティや 誇りの醸成, 新たな人的交流, 人材育成などの 効果が特徴的と指摘する. 山口ら ${ }^{8)}$ はスポーツ イベント開催の社会効果を「スポーツイベント 開催を通じて, 生活の質, ライフスタイル, コ ミュニティ構造, 行動パターン, 個人及び集団 の価值体系が短期的に変化することの知覚」と 定義づけ, 押見 ${ }^{9)}$ は同社会効果に関して11因子 からなる尺度開発を行い, そのなかには「地域 のイメージ・認知度の向上」「多様性への理解・ 新たな機会の獲得」「地域での一体感向上」「快 感情の獲得」「地域での会話促進」「スポーツへ の興味促進」などが含まれる。

スポーツが地域に及ぼす効果を俯瞰すると, 「地域アイデンティティ・誇り」「地域の一体 感」「地域愛着」など, いわば「地域に対する 肯定的な感情」の醸成は, 社会効果の一画をな すものとして頻出しており特徽的といえる. 例 えば「地域アイデンティティ・誇り」とは, 地 域が何らかの理由で賞賛されると自身も誇らし く感じるなど, 地域と自身のアイデンティティ が一致した状態を示すこととされ, 社会的アイ
デンティティ理論 ${ }^{10) 11)}$ に基づく概念である.「地 域愛着 (Place Attachment)」も社会的アイデ ンティティ理論から導かれ,「人々と特定の地 域を結びつける感情的な絆 $\rfloor^{12)}$ が代表的な定義 とされる。従来,「地域に対する肯定的な感情」 とスポーツの因果関係については, いずれを独 立変数あるいは従属変数とするかが判然としな い面もあったが, 菅ら ${ }^{13)}$ はチーム・アイデンティ フィケーション（以下，チームID）と地域愛 着の因果関係について, 愛媛県今治市の住民を 対象に縦断的調查を行い，「FC今治」に対する チームIDを上昇させた地域住民（チームID 上 昇群）は，上昇しない住民（非上昇群）に比べ て地域愛着度を有意に高めている可能性を示唆 した。しかし，地域愛着に影響を及ぼす要因は 多様であり ${ }^{14)}$-17), 上昇には一定の期間を要す $ろ^{17)}$ ことも鑑みて, チームIDと地域愛着を媒 介する何らの変数の存在の有無を検証すべきと 指摘した。「地域に対する肯定的な感情」の醸 成の過程を媒介変数にも考慮しつつ検討するこ とは, スポーツが地域に及ぼす社会効果の一端 をより明らかにするものとして学術的意義があ ると思われる. そこで次節ではこの着眼点に基 づき, 地域愛着に対象を絞り, その影響要因や 醸成される過程に関する先行研究の検討を進め ることとする.

\section{2. 先行研究の検討}

地域愛着に影響を及ぼす構造に関して, 引地 $ら^{18)}$ は「地域の社会的環境に対する評価」(以 下, 社会的評価) と「地域の物理的環境に対す る評価」(以下, 物理的評価) を挙げ, 両者の 評価が高いほど地域愛着も高いと指摘する。さ らに, 社会的評価は物理的評価に比べて地域愛 着をより高めるとし，「地域での経験の質」を 通じた社会的評価の上昇が地域愛着の上昇を導 くことを示唆した，その社会的評価の尺度は, 「日頃, 地域の人々と交流を持つことが多い」「毎 年, この地域で行われる祭りやイベントを楽し みにしている」「この地域の人々は親切だと思 う」「この地域の治安は良い」の 4 項目から構 


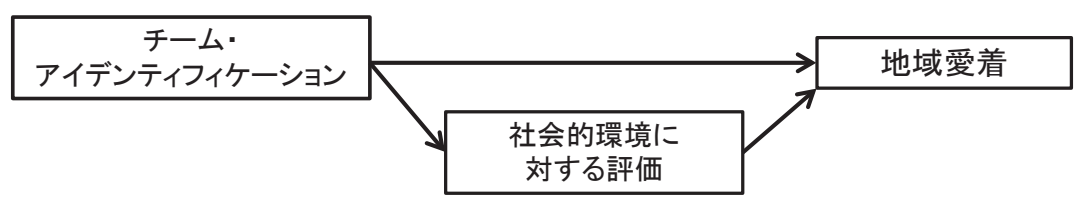

図 1 本研究の仮説モデル

成され，主として「地域社会との結びつき」の 多寡により社会的評価が形成されると換言でき る.

本研究の問題意識に照らしてここで問うべき は,「チームIDの上昇」は果たして社会的評価 を上昇させるような「地域の経験」になり得る のかであろう。「チームIDを上昇させた住民」 が「地域社会との結びつき」を強めて社会的評 価を上昇させる関係性が見出されるとすると, 「チームIDの上昇は, 社会的評価を媒介变数と して地域愛着の上昇を導く」との視座も開かれ る.

スポーツと「地域社会との結びつき」に関わ る先行研究に触れると, ソーシャル・キャピ タルを対象とする研究群に行き当たる。ソー シャル・キャピタルの定義は, Pattnam ${ }^{19)} に よ$ る「人々の協調行動を活発にすることによって 社会の効率性を改善できる, 信頼・規範・ネッ トワークといった社会組織の特徴」に代表され, 地域スポーツの振興や住民のスポーツ参加は, ソーシャル・キャピタルの涵養を通じて共同体 意識の促進 ${ }^{20}$ や地域コミットメントの拡大 ${ }^{21)}$, 地域活動の促進 ${ }^{22)}$, あるいは社会的ネットワー

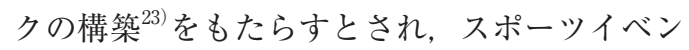
卜開催も類似の効果があるとされる ${ }^{24)}$.また, プロバスケットボールチームの観戦者は, 観戦 に訪れない住民よりもソーシャル・キャピタル 度や地域活動への参加程度が高いとする結果も 示されている25).

こうして見ると，スポーツをする・見る等の 行為は, 地域住民の「地域社会との結びつき」 を高めることがあり得るとされ, 地域を拠点と するプロスポーツチームに対するチームIDの 上昇も,その契機となる可能性は否定できない.
従って,「チームIDの上昇は, 社会的評価を媒 介変数として地域愛着の上昇を導く」とする視 座も妥当性を欠くとはいえず，その関係構造に 着眼することは，スポーツが地域に及ぼす社会 効果の一端を明らかにする点で学術的意義を有 するといえる.

以上をふまえて, 本研究では「チームIDの 上昇は, 社会的評価の上昇を伴い, 地域愛着の 上昇を導く」との仮説を設定し，その検証を目 的とした (図 1)。なお本研究では, 菅ら ${ }^{13)}$ の 論考と同じく，チームIDは「チームと自己を 同一化・同一視する態様」沜, 地域愛着は前述 にある「人々と特定の地域を結びつける感情的 な絆」を定義として論を進めることとする.

\section{3. 方法}

\section{1 調査対象地の選定}

本研究は, チームID と地域愛着の因果関係に 関する考察に基づき，両者の媒介变数に関する 検証を目的とすることから, 調查対象は菅ら ${ }^{13)}$ の先行研究と同じく愛媛県今治市 (人口約 16 万 人）の住民とし，チームIDの測定対象チーム も同様に「FC今治」とした。

$「 F C$ 今治」は1976年に設立され, 2016年シー ズンに四国リーグおよび全国地域サッカーチャ ンピオンズリーグで優勝して JFL（日本フット ボールリーグ）に昇格し，2018年はJFLで 2 年 目のシーズンを迎えている (2018年 5 月現在). 2017 年 9 月に最大 5,000 人収容のスタジアムを 完成させ, JFLの 1 試合あたり平均観客数（約 800人：2017年）を 4〜 5 倍前後上回る $3 \sim 4$ 千人台の観客数を記録するなど, 四国リーグ所 属時からのここ数年間でチームIDを上昇させ る住民が増加していることが推察される。 チー 
ムIDを上昇させる住民のサンプル数が一定程 度できることで, 地域社会との結びつきの程度 や社会的評価など他の变数の時系列の変化の有 無を捉える点で調査対象として適していると判 断した.

\section{2 予備調査}

引地ら ${ }^{18)}$ は, 社会的環境に対する評価と物理 的環境に対する評価が地域愛着に影響を及ぼす 構造（以下, 地域愛着影響構造）を示唆した. 同調査は全国16市町の選挙人名簿から無作為抽 出した4,000名をもとにサンプル収集しており， 各地域に通用する一般性の高い構造を示したと 考えられる. しかし, この地域愛着影響構造 が本研究の調査対象の今治市にも適合するか否 かをそもそも検討する必要性があると考えられ る. そこで, 今治市内在住の社会調査モニター を対象とするインターネット調査を 2 回実施す ることとした. 調査時期は 2015 年 4 月と同年 12 月とした。同時期の「FC今治」はJFLの下位 カテゴリーの地域リーグ（四国リーグ）に所属 し， 1 試合あたりの観客数は $500 １, 000$ 人程度 であり, 今治市の住民間で同チームに対する関 心や興味は, 現在（2018年）に比較して低い状 態と見なすことができる. 即ち, 同チームに関 するバイアスは無視できる状況下でのデータ収 集が可能として, 調査時期を設定した.

調査項目は, 引地ら ${ }^{13)} に よ り$ 信頼性が確認さ れた「地域環境に対する評価」尺度の構成概念 である物理的評価 $(\alpha=.62)$ と社会的評価（ $\alpha$ $=.62)$, 及び「地域に対する愛着」尺度 $(\alpha$ =.84）をもとに, スポーツ科学研究科でスポー ツマネジメントを専門とする教員 1 名および同 専攻の博士課程学生 2 名による検討を行ったう えで，以下の調査項目を設定した。選択肢には $\lceil 1$ 全くそう思わない」から「7 強くそう思う」 の 7 段階リッカート法を用いた。

収集したデー夕は, 社会的評価・物理的評価・ 地域愛着それぞれについて 1 回目と 2 回目の全 項目平均值を比較し ( $\mathrm{t}$ 検定), 期間推移によ る変化の有無を検証した。また, 地域愛着を従
属変数, 社会的評価および物理的評価を独立変 数とする重回帰分析を行い, 社会的評価および 物理的評価が地域愛着に及ぼす影響の有無を確 認することとした．重回帰分析は連続的な変数 について行う分析であり，7段階リッカート法 に見られるような離散的な質的変数の分析には 適さないと指摘されうるが, 本研究では引地ら 13)に倣って重回帰分析を採用する立場を取り, 同先行研究と本研究の分析結果を比較すること とした。なお，本研究で収集したデー夕をもと に，「地域環境に対する評価」尺度および「地 域に対する愛着」尺度の信頼性および妥当性の 確認を行ったうえで分析を進めることとした.

*物理的評価に関する項目：

『今治市』を思い浮かべて, 以下の質問にど の程度当てはまるかお答えください.

・この地域の街並みはきれいだと思う

・この地域の自然はきれいだと思う

・この地域の街並みからは歴史が感じられる

-大きな山や建造物など, 地域の人が皆知っ ている, 地域のシンボルがある

・この地域の名産品は, 他の地域の人に勧 められる

*社会的評価に関する項目：

『今治市』を思い浮かべて, 以下の質問にど の程度当てはまるかお答えください.

・日頃，地域の人々と交流を持つことが多い

-日頃, 地域の人々と一緒に活動する機会 が多い

- 毎年, この地域で行われる祭りやイベン トを楽しみにしている

・この地域には, 生活面で協力し合える人 がいる

・この地域の治安は良い

*地域愛着に関する項目 :

『今治市』を思い浮かべて, 以下の質問にど の程度当てはまるかお答えください.

・この地域に, 今後も住み続けたいと思う

・自分は, 自分が住んでいる地域社会の一 員だと思う 
・自分にとって, この土地はなくてはなら ない場所である

・地域の人々は自分にとって大切な存在で ある

・この土地は自分にとって住みよい場所で ある

\section{3 本調査の時期と項目}

方法 1 において今治市にも地域愛着影響構造 が適用されることを前提に, 方法 1 と異なる時 期に, 今治市に在住する社会調査モニターを対 象とするインターネット調查を計 3 回実施し, 同一人物による 3 回連続回答のデータを分析対 象サンプルとすることとした。

インターネット調査の実施は, I 期 : 2016年 8 月 26 日〜 9 月 13 日, II 期：2016年 12 月 7 日〜 19日， III 期：2017年 5 月15日〜28日の計 3 回 とした。 I 期および II 期は，菅ら ${ }^{13)}$ が実施した 調查時に本研究の調査項目（下記）も追加し, III 期は本研究独自に調查を設定した。 I 期から III 期にかけては「FC今治」がJFL昇格を決め て, 同リーグでの公式戦が開始された時期に重 なる。この期間には, チームの好戦績やメディ ア露出の増加による認知や関心・興味の拡大, それに伴う観客数の増加などからチームIDを 上昇させた住民のサンプルが一定程度確保でき ると考えられることから調査時期に設定した.

$\mathrm{I} \sim \mathrm{III}$ 期の調査項目は, 人口統計的項目, チー ムIDに関する項目, 地域愛着に関する項目, 地域社会との結びつきに関する項目とし， III 期 のみ社会的評価に関する項目を追加してデータ 収集を行った。

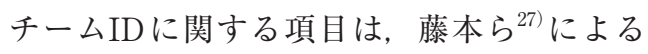
チームIDと地域愛着に関連する縦断的調査で 用いられ，信頼性と妥当性が確認される測定尺 度 (6 因子: 個人的評価 $(\alpha=.84)$, 公的評価 $(\alpha$ $=.89)$, 心理的結びつき $(\alpha=.89)$, 依存意識 $(\alpha$ $=.95)$, 行動的関与 $(\alpha=.75)$, 認知・気づき （ $\alpha=.89 ）$ 計24項目）に準拠することとした. 事前にスポーツ科学研究科でスポーツマネジメ ントを専門とする教員及び同専攻の博士課程学
生各 1 名を交えて, 本研究の調査対象に当ては めて検討した結果, 削除や修正を行う必要性を 認めず，全ての因子及び項目（下記）を採用し た. 測定には「1 全く当てはまらない」から「7 非常に当てはまる」の 7 段階リッカート法を用 いることとした。

*「個人的評価」 3 項目 : FC 今治を応援する ことは良いことであると感じる $/ \mathrm{FC}$ 今治を 応援することをうれしく思う $/ \mathrm{FC}$ 今治を応 援している自分を誇りに思う

*「公的評価」 3 項目 : FC 今治は人々から良 いイメージを持たれている/人々は FC今治 のことを良く思っている／人々は， FC今治 について好意的な意見を持っていると思う

*「心理的結びつき」 5 項目：FC今治は, 私 自身を表現する重要なポイントである／誰か がFC今治を称賛すると，自分がほめられた ような気持ちになる/私は, $\mathrm{FC}$ 今治の一員 であるという意識を持っている/私は, FC 今治に強い愛着を持っている $/ \mathrm{FC}$ 今治の成 功は, 私の成功のように感じる

*「依存意識」 4 項目：FC今治は, 私の生活 を左右する $/ \mathrm{FC}$ 今治は, 私の生活に影響す る $/ \mathrm{FC}$ 今治の変化は, 私の生活も変える / $\mathrm{FC} 今$ 治の活動は，私個人にも影響を与える

*「行動的関与」 4 項目 : 私は, FC今治の活 動の支援をする方だ／私は，FC今治につい て自ら他人に話をする方だ/私は，FC今治 グッズを進んで買う方だ/私は，FC今治の 試合結果を積極的に知ろうとする方だ

*「認知・気づき」5 項目：私は, FC今治の 歴史を知っている/私は, FC今治について 多くのことを知っている/私は, FC今治の 成功も挫折も知っている/私は, FC今治の クラブ事情について知っている／私は, FC 今治が地域で行っている活動を知っている

地域愛着に関する項目では, 鈴木・藤井 ${ }^{28)}$ による縦断的調查の事例で用いられ，信頼性と 妥当性が確認される地域愛着の測定尺度（3因 
子: 選好 $(\alpha=.91)$, 感情 $(\alpha=.89)$, 持続願 望 $(\alpha=.83)$ 計13項目)に準拠することとした. 「選好」は地域に対する好き嫌いの程度,「感情」 は地域を大切に思う気持ちなど, 表層的な好き 嫌いよりも深みのある思いの程度,「持続願望」 は地域の永続を願う程度とされる。この 3 因子 間の関係について,「選好」は比較的短期間に 醸成される一方,「感情」や「持続願望」は,「選 好」の程度に影響を受けつつ, 長期間に䤑成さ れることが示されている28).

なお, チームIDと同様にスポーツ科学研究 科でスポーツマネジメントを専門とする教員及 び同専攻の博士課程学生各 1 名を交えた検討の 結果, 「歩くのは気持ちよい」(選好), 「愛着を 感じている」(感情) の 2 項目は不採用とした. 前者について, 今治市は市街地や郊外を徒歩で 移動する住民は限定的で, 自動車や二輪車・自 転車の移動が主であることを理由とした。後者 については, 地域愛着の測定尺度のなかで「愛 着」の程度を直接的に問うのは回答者が混乱を きたす可能性があることを理由とした. 従って, 3 因子11項目（下記）を採用し，「1 全く当て はまらない」から「7 非常に当てはまる」の 7 段階リッカート法を用いることとした。

*「選好」 5 項目：今治市が好きだ／今治市で はリラックスできる/今治市にお気に入りの 場所がある/今治市は住みやすいと思う／今 治市の雲囲気や土地柄が気に入っている

*「感情」 4 項目 : 今治市にずっと住み続けた い/今治市に自分の居場所がある気がする／ 今治市は自分のまちだという感じがする／今 治市は大切だと思う

*「持続願望」 2 項目：今治市にいつまでも変 わって欲しくないものがある/今治市からな くなってしまうと悲しいものがある

さらに, 地域社会との結びつきに関する項目 として, 人間関係の変化や地域活動の参加経験・ 意向の設問を用意した (下記).

【人間関係の変化】
*「FC今治」を TVや新聞で目にする，周囲 の人と話題にする, 試合観戦やイベントへの 参加等を通じて, あなたの周りの人間関係に 変化は感じますか?

（選択肢：「1 人間関係がとても衰えたと感 じる」から「7 人間関係がとても豊かになっ たと感じる」の 7 段階リッカート法)

【地域活動の参加経験】

*あなたは地元（今治市）の町内会や地域組織 （自治会, PTA, 各種組合など）の活動にど の程度参加していますか?

*あなたは地元（今治市）でのボランティア活

動に, どの程度参加していますか?

*あなたは今治で行われるイベント（祭り, 催

しもの等) にどの程度参加していますか？

（選択肢：「1 全く参加していない」から「7 すべて参加している」の 7 段階リッカート法) 【地域活動への参加意向】

*あなたは今後, そうした町内会や地域組織の 活動に, どの程度参加しょうと思いますか? *あなたは今後, そうしたボランティア活動に どの程度参加しょうと思いますか?

*あなたは今後, そうしたイベントにどの程度 参加しようと思いますか?

（選択肢：「1 絶対に参加したくない」から $\lceil 7$ 積極的に参加したい」の 7 段階リッカー 卜法)

また，III期の設問には社会的評価の測定項目 も盛り达むこととし，方法 1 で用いた社会的評 価の測定項目と同内容とした. I 〜 III 期のチー ムIDおよび地域愛着の測定尺度は, 収集した データを元に信頼性および妥当性の確認を行っ たうえで分析を進めることとした。

\section{4 本調査の分析方法}

$\mathrm{I} \sim \mathrm{II}$ 期の有効回答の中から, 同一人物によ る 3 回連続回答のサンプルを抽出して分析対象 とし，以下の手順で分析を進めることとした。

はじめに，I〜期間にチームIDの全項目 平均值が増加し, かつ III 期の同值が4.00（ 7 段 
表 1 回答者の概要

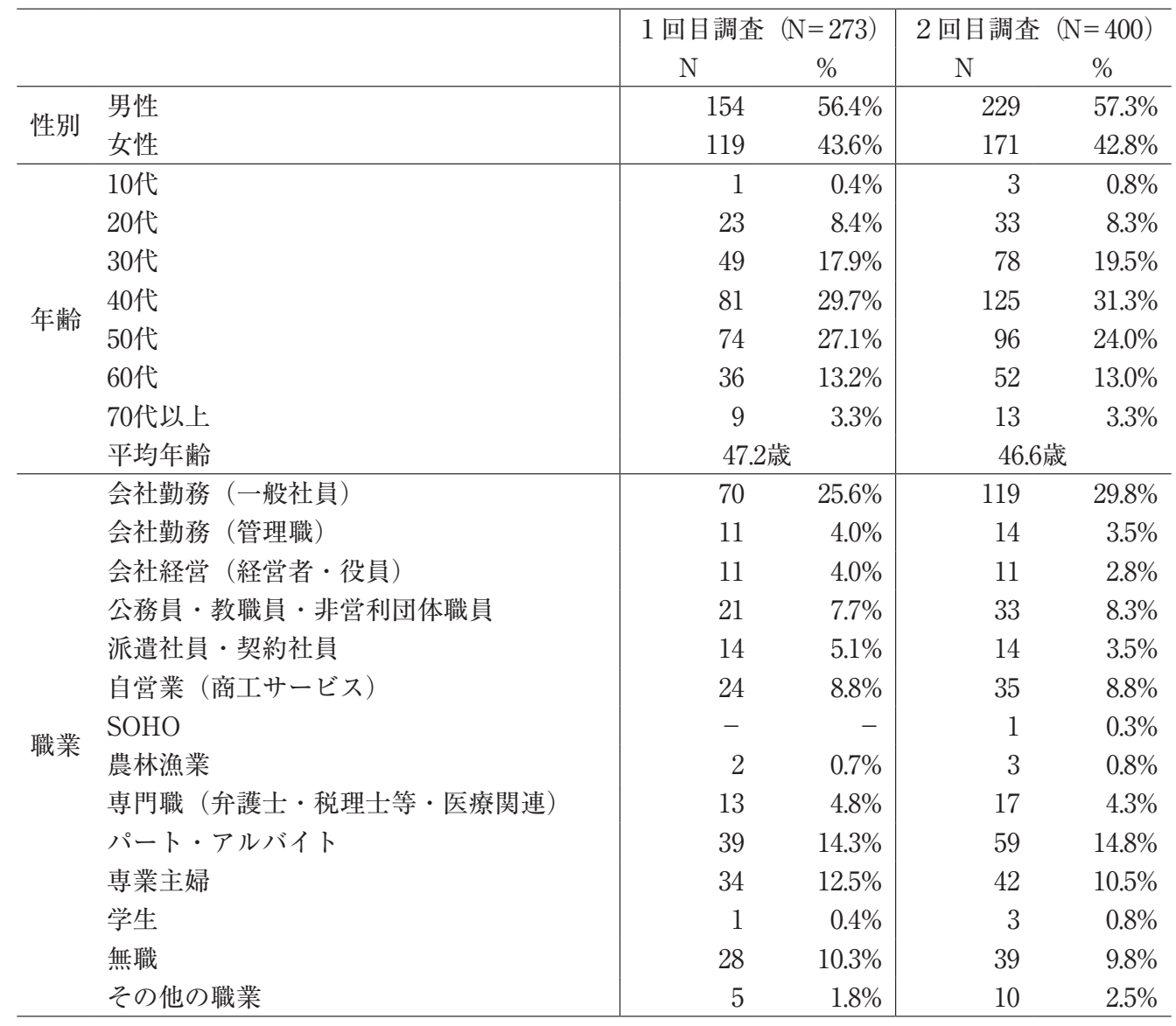

階リッカート法の中央の值) を上回るサンプル を「チームID上昇群」, 同群に該当しないサン プルを「チームID非上昇群」と区分すること とした。そそのうえで両群の地域愛着の変化を二 元配置分散分析により比較し, チームIDの上 昇に伴う地域愛着の上昇の有無を検証すること とした。その次に，「チームID上昇群」「非上 昇群」間の「地域社会との結びつき」項目の変 化を二元配置分散分析で比較した。 また, 両群 間の社会的評価の差異を $\mathrm{t}$ 検定により検証し た. 分析にはSPSS Statics 23を用いた。

なお，両群の区分けの基準に関して，「チー 厶ID上昇」を文字通り捉えると, 例えば $1.00 か$ ら2.00への変化も「上昇」と見なされる. しか し, III 期の時点におけるチームIDが 7 段階の
中央の值である4.00を下回る回答者は, FC今 治に対する関心や興味が高いとはいえないこと から，4.00を上回る回答者のみを「チームID上 昇群」に区分することが妥当と見なした。ある いは群区分を行わずに 3 回連続回答のサンプル を一括で扱い, チームIDと地域愛着や地域社 会との結びつきの変化を測定することも考えら れる. しかし, 仮にその方法で 3 変数が共に上 昇する結果を得たとしても, チームIDの上昇 を主要因として地域愛着や地域社会とのむすび つきが上昇したとは言い切れず，調査期間内に 地域で起きた FC 今治とは無関係の事象や, 住 民の何らかの経験が影響した可能性を排除でき ない.そこで「チームID上昇群」「非上昇群」 に区分し, 両者を比較する方法が有効とされる. 
表 2 物理的評価・社会的評価 - 地域愛着の $\mathrm{t}$ 検定

\begin{tabular}{|c|c|c|c|c|c|c|c|c|c|c|c|c|c|c|c|}
\hline & \multicolumn{2}{|c|}{ 物理的評価 } & \multirow{2}{*}{ 自由度 } & \multirow{2}{*}{$\mathrm{t}$ 值 } & & \multicolumn{2}{|c|}{ 社会的評価 } & \multirow{2}{*}{ 自由度 } & \multirow{2}{*}{$\mathrm{t}$ 值 } & & \multicolumn{2}{|c|}{ 地域愛着 } & \multirow{2}{*}{\multicolumn{2}{|c|}{ 自由度 $t$ 值 }} & \\
\hline & M & $\mathrm{SD}$ & & & & M & $\mathrm{SD}$ & & & & M & $\mathrm{SD}$ & & & \\
\hline 1 回目調査 $(N=273)$ & 4.57 & 1.12 & 671 & 086 & $n_{c}$ & 4.04 & 1.17 & 671 & 203 & * & 4.64 & 1.35 & 671 & 113 & $n s$ \\
\hline 2 回目調査 $(\mathrm{N}=400)$ & 4.49 & 1.09 & 011 & 0.00 & 11.s. & 3.87 & 1.01 & 011 & 2.05 & $r$ & 4.53 & 1.29 & 011 & 1.15 & 11.5. \\
\hline
\end{tabular}

\section{4. 結果}

\section{1 予備調查の結果}

1 回目調查の有効回答数は273件, 2 回目調 查は400件となった。性別比は, 1 回目調查が 男性 $56.4 \% （ \mathrm{n}=154 ） \cdot$ 女性 $43.6 \% （ \mathrm{n}=119 ）$, 2 回目調查が男性 $57.3 \% （ \mathrm{n}=229 ） \cdot$ 女性 $42.8 \%$ $(\mathrm{n}=171)$ であった. 年代は 1 回目, 2 回目と もに 40 代が最も多く, 50 代と30代が続いてい る. 平均年齢は 1 回目が 47.2 歳, 2 回目が 46.6 歳で, 今治市の住民の平均年齢（48.4歳：2015 年度住民基本台帳統計）との差異は最大でも 1.8 歳に留まった. 職業は会社勤務 (一般社員), パー ト・アルバイト，専業主婦が上位を占めている ほか, 定年リタイア層を中心とする無職も比較 的多い傾向が表れた（表 1 ）。

収集したサンプルから「地域環境に対する評 価」尺度の信頼性及び妥当性を検討したところ， 物理的評価の $\alpha$ 係数 $=.84 \mathrm{AVE}=.51$, 社会的 評価は $\alpha$ 係数 $=.86 \mathrm{AVE}=.58$ を示した. $\alpha$ は. 70 以上, AVEは.50以上が基準とされ，いずれも 基準を満たした. GFI, AGFI, CFI, RMSEA の算出も行い, $\mathrm{GFI}=.827, \mathrm{AGFI}=.720, \mathrm{CFI}$ $=.860, \mathrm{RMSEA}=.149$ の 数值を得た. GFI, AGFI, CFIは.90以上，RMSEAは.05以下を基 準としたところ, GFI とCFIは基準に近い值を 示した。信頼性と妥当性の検証の結果, 基準を 満たさない数值が存在することから検討余地を 残すものの， $\alpha$ 係数とAVEは基準を満たし， 一定の信頼性の確認ができるとの判断に加え て, この予備調查は地域愛着影響構造が今治市 にも適合するかの比較検証が目的であることも 鑑み, 内容的妥当性から項目を削除するのは好 ましくないと判断し，分析を進めることとした.
また，地域愛着に関する項目の信頼性及び妥 当性も検討した. Chronbach $\alpha$ 係数を算出した 結果， $\alpha=.93$ を示した。ささらに，収束的妥当 性の值を示す AVEと各項目の標準化倸数も算 出し, $\mathrm{AVE}=.73$, 各項目の標準化係数は .68 から.77の範囲となった．AVEは.50以上が基 準值とされ，基準を満たすことから分析を進め ることとした

1 回目調查と 2 回目調査の物理的評価・社会 的評価・地域愛着（いずれも全項目平均値）の $\mathrm{t}$ 検定を行った結果, 物理的評価と地域愛着は 有意な变化が認められなかった一方, 社会的評 価は有意差が認められ，1回目より 2 回目が低 下した（表2）。

地域愛着（全項目平均值）を従属变数, 物理 的評価および社会的評価（いずれも全項目平均 值）を独立変数とする重回帰分析を 1 回目， 2 回目の数值それぞれにおいて行った. その結果, 両回ともに物理的評価㧍よび社会的評価は地域 愛着に正の影響を及ぼしていることが明らかに なった（表 3）。1 回目の物理的評価は標準化 係数 $\beta=.25(p<.001)$, 社会的評価は. $51(p$ $<.001), 2$ 回目の物理的評価は.31 $(p<.001)$, 社会的評価は. $40(p<.001)$ となり, 両回とも 社会的評価が物理的評価よりも高い影響を及ほ す結果を得た。この結果から，今治市に扔いて も地域愛着影響構造が適用されることが明らか になった。

\section{2 本調查の結果}

インターネット調查の有効回答数は, I 期が 495件， II 期が494件， III 期が500件であり， I 期〜期を通じて同一人物による 3 回連続回答 数は129件となった．この分析対象サンプル (n 
表 3 地域愛着と物理的評価・社会的評価の重回帰分析

\begin{tabular}{|c|c|c|c|}
\hline & \multicolumn{2}{|c|}{ 従属変数 } \\
\hline & & \multicolumn{2}{|c|}{ 地域愛着（全項目平均値） } \\
\hline & & 1 回目調查 & 2 回目調查 \\
\hline \multirow{2}{*}{ 独立変数 } & 物理的評価（全項目平均値） & $.25^{* * *}$ & $.31 * * *$ \\
\hline & 社会的評価（全項目平均値） & $.51 * * *$ & $.40 * * *$ \\
\hline
\end{tabular}

表 4 回答者の概要

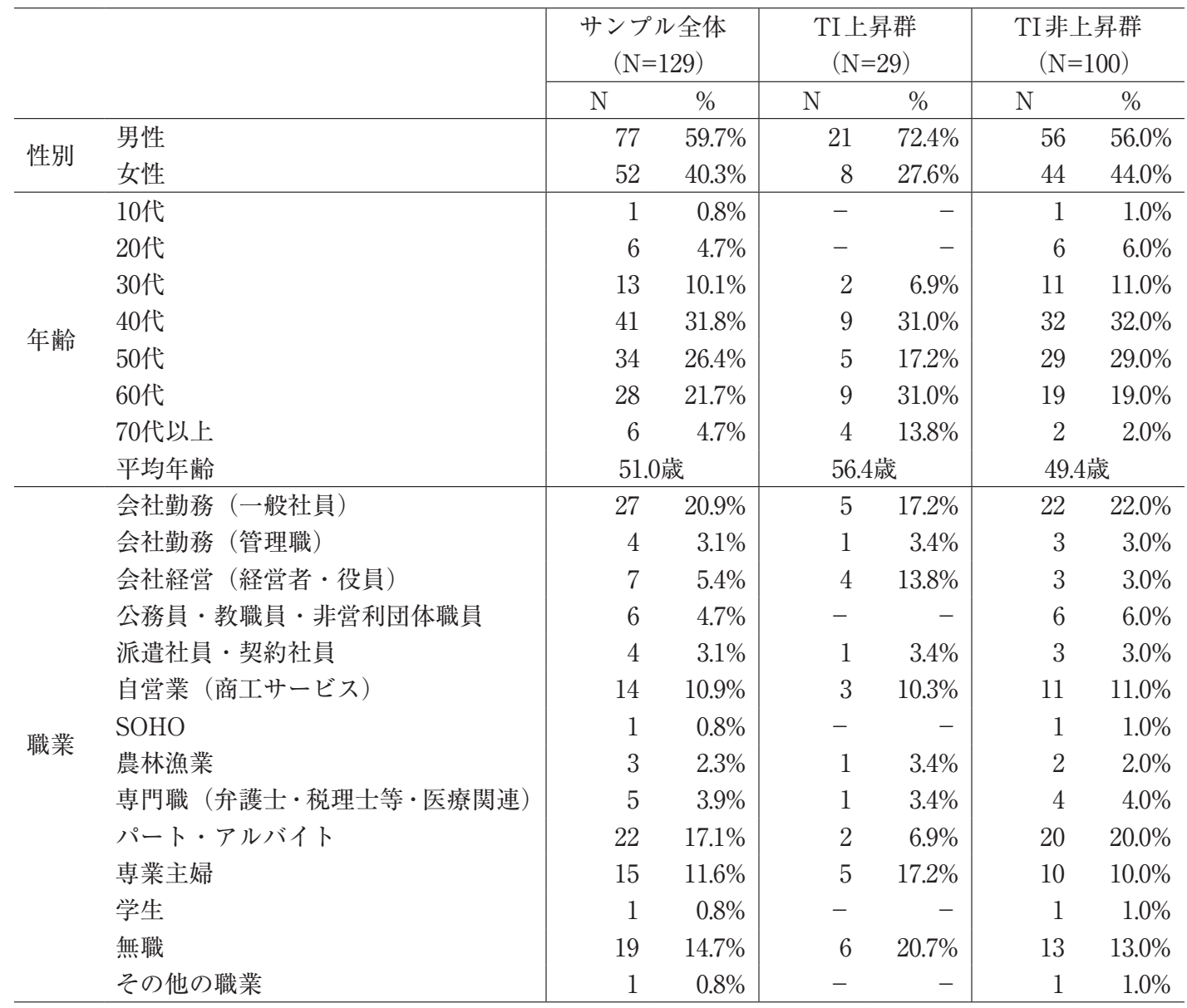

=129）の性別比は，男性が59.7\%（ $\mathrm{n}=77 ）$. 女性が $40.3 \% （ \mathrm{n}=52 ）$ で，年代は40代が $31.8 \%$ ( $\mathrm{n}=41)$ で最多で，50代が $26.4 \%(\mathrm{n}=34), 60$ 代が $21.7 \% （ \mathrm{n}=28 ）$ と続き，以下 30 代が $10.1 \%$ $(\mathrm{n}=13) ， 20$ 代が $4.7 \%(\mathrm{n}=6)$ ，70代以上が $4.7 \%(n=6), 10$ 代が $0.8 \%(n=1)$ となった.
平均年齢は51.0歳で, 今治市の住民の平均年齢 （48.4歳：2015年度住民基本台帳統計）との差 異は2.6歳に留まった。職業は多数上位の会社 勤務 (一般社員), パート・アルバイト, 専業 主婦を合わせて $49.5 \%(\mathrm{n}=64)$ と約半数を占 めたほか, 自営業 $(10.9 \% \mathrm{n}=14)$ や, 定年リ 
表 5 「チームID上昇群」と「非上昇群」の地域愛着の変化

\begin{tabular}{|c|c|c|c|c|c|c|c|c|c|}
\hline & \multicolumn{2}{|c|}{ I 期 } & \multicolumn{2}{|c|}{ II 期 } & \multicolumn{2}{|c|}{ 吕期 } & \multicolumn{3}{|c|}{$\mathrm{F}$ 值 } \\
\hline & M & $\mathrm{SD}$ & M & SD & M & $\mathrm{SD}$ & $\begin{array}{c}\text { 交互作用効果 } \\
(\text { チーム ID × } \\
\text { 期間推移 })\end{array}$ & $\begin{array}{c}\text { 主効果 } \\
\text { (チームID) }\end{array}$ & $\begin{array}{c}\text { 主効果 } \\
\text { (期間推移) }\end{array}$ \\
\hline \multicolumn{10}{|l|}{ 地域愛着 全項目平均 } \\
\hline $\begin{array}{r}\text { チーム ID 上昇群 }(\mathrm{N}=29 \text { 以下同 }) \\
\text { チームID非上昇群 }(\mathrm{N}=100 \text { 以下同 })\end{array}$ & $\begin{array}{l}4.50 \\
5.00\end{array}$ & $\begin{array}{l}1.16 \\
1.29\end{array}$ & $\begin{array}{l}5.09 \\
4.90\end{array}$ & $\begin{array}{l}1.10 \\
1.34\end{array}$ & $\begin{array}{l}5.43 \\
4.65\end{array}$ & $\begin{array}{l}1.09 \\
1.23\end{array}$ & $6.46^{* *}$ & 0.90 & 1.52 \\
\hline \multicolumn{10}{|l|}{ 選好 } \\
\hline $\begin{array}{r}\text { 上昇群 } \\
\text { 非上昇群 }\end{array}$ & $\begin{array}{l}4.52 \\
5.09\end{array}$ & $\begin{array}{l}1.09 \\
1.30\end{array}$ & $\begin{array}{l}5.17 \\
4.89\end{array}$ & $\begin{array}{l}1.13 \\
1.36 \\
\end{array}$ & $\begin{array}{l}5.47 \\
4.72\end{array}$ & $\begin{array}{l}1.10 \\
1.26\end{array}$ & $6.92^{* *}$ & 0.78 & 1.44 \\
\hline \multicolumn{10}{|l|}{ 感情 } \\
\hline $\begin{array}{r}\text { 上昇群 } \\
\text { 非上昇群 }\end{array}$ & $\begin{array}{l}4.45 \\
4.95 \\
\end{array}$ & $\begin{array}{l}1.22 \\
1.46 \\
\end{array}$ & $\begin{array}{l}5.01 \\
4.90 \\
\end{array}$ & $\begin{array}{l}1.34 \\
1.48 \\
\end{array}$ & $\begin{array}{l}5.49 \\
4.62 \\
\end{array}$ & $\begin{array}{l}1.21 \\
1.35 \\
\end{array}$ & $6.00^{* *}$ & 0.74 & 1.71 \\
\hline \multicolumn{10}{|l|}{ 持続願望 } \\
\hline $\begin{array}{r}\text { 上昇群 } \\
\text { 非上昇群 }\end{array}$ & $\begin{array}{l}4.52 \\
4.77 \\
\end{array}$ & $\begin{array}{l}1.48 \\
1.49 \\
\end{array}$ & $\begin{array}{l}5.05 \\
4.91 \\
\end{array}$ & $\begin{array}{l}1.29 \\
1.47 \\
\end{array}$ & $\begin{array}{l}5.19 \\
4.50 \\
\end{array}$ & $\begin{array}{l}1.13 \\
1.32 \\
\end{array}$ & 2.54 & 1.30 & 1.32 \\
\hline
\end{tabular}

タイア層を中心に無職 $(14.7 \% \mathrm{n}=19)$ も比較 的多い傾向が表れた（表 4).

群の区分を行った結果， I 〜 III期間にチーム IDの全項目平均值が増加し, かつ III 期の同值 が4.00を上回る「チームID 上昇群」は29件,「チー ムID非上昇群」は 100 件が該当した. チームID 及び地域愛着の測定尺度の信頼性と妥当性を検 討したところ，チームID測定尺度の構成因子 の $\alpha$ 係数及びAVEは, 「個人的評価」（ $\alpha=.95$ $\mathrm{AVE}=.86)$,「公的評価」 $(\alpha=.95 \mathrm{AVE}=.86)$, 「心理的結びつき」 $(\alpha=.97 \mathrm{AVE}=.86)$,「依 存意識」 $(\alpha=.98 \mathrm{AVE}=.94)$, 「行動的関与」 $(\alpha=.97 \mathrm{AVE}=.88)$, 「認知・気づき」 $(\alpha=.98$ $\mathrm{AVE}=.91)$ を示した。構成概念の妥当性を示 す値は, $\mathrm{GFI}=.713, \mathrm{AGFI}=.633, \mathrm{CFI}=.928$, RMSEA = .117を示した.

地域愛着の測定尺度は, 「選好」（ $\alpha=.94$ $\mathrm{AVE}=.77)$,「感情」 $(\alpha=.95 \mathrm{AVE}=.82)$,「持 続願望」（ $\alpha=.82 \mathrm{AVE}=.73 ）$ となり, GFI $=.873, \mathrm{AGFI}=.795, \mathrm{CFI}=.960, \mathrm{RMSEA}$ $=.109$ を示した。基準值は $\alpha=.70$ 以上, AVE $=.50$ 以上とされ, GFI, AGFI, CFIは.90以上, RMSEA は.05以下で当てはまりが良いとされ る. 本研究では, $\alpha$ とAVEが基準值を満たし, CFIが.90以上の值を得たことから, 許容範囲
と判断して分析を進めることとした.

I 〜 III 期における「チームID上昇群」と「チー 么ID非上昇群」の地域愛着の各項目平均值の 比較を二元配置分散分析により行った結果, チームID と期間推移が地域愛着に与える交互 作用効果 $(\mathrm{F}(1,127)=6.46 p<.01)$ が統計的 に有意であった（表 5)。一方，チームIDが地 域愛着に及ぼす主効果, 及び期間推移が地域愛 着に及ぼす主効果は有意水準に満たなかった。

地域愛着の因子の交互作用効果は「選好」( F $(1,27)=6.92 p<.01)$ 及び「感情」 $(\mathrm{F}(1,127)$ $=6.00 p<.01)$ が統計的に有意であった. 一方, 因子「持続願望」の交互作用効果は有意水準を 満たさなかった。チームIDが地域愛着に及ぼ す主効果, 期間推移が地域愛着に及ぼす主効果 は，3因子とも有意水準に満たなかった。

次に,「地域社会との結びつき」に関する設 問について,「チームID 上昇群」と「非上昇群」 の比較（二元配置分散分析）を行った（表6).

「人間関係の変化」は, 交互作用効果 $(\mathrm{F} （ 1$, 127） $=3.29 p<.05 ）$ が有意水準を満たし，「チー ムID 上昇群」が高い值を示した. 主効果はチー ムID, 期間推移ともに有意水準を満たさなかっ た。

地域活動の参加経験は,「町内会や地域組織」 
表 $6\lceil$ 「チームID上昇群」と「非上昇群」の「地域社会との結びつき」項目の比較

\begin{tabular}{|c|c|c|c|c|c|c|c|c|c|}
\hline & \multicolumn{2}{|c|}{ I 期 } & \multicolumn{2}{|c|}{ II 期 } & \multicolumn{2}{|c|}{ 正期 } & \multicolumn{3}{|c|}{$\mathrm{F}$ 值 } \\
\hline & M & $\mathrm{SD}$ & M & $\mathrm{SD}$ & M & $\mathrm{SD}$ & $\begin{array}{c}\text { 交互作用効果 } \\
(\text { チームID × } \\
\text { 期間推移 })\end{array}$ & $\begin{array}{l}\text { 主効果 } \\
\text { (チームID) }\end{array}$ & $\begin{array}{l}\text { 主効果 } \\
\text { (期間推移) }\end{array}$ \\
\hline \multicolumn{10}{|l|}{ 人間関係の変化 } \\
\hline $\begin{array}{r}\text { チームID 上昇群（N=29 以下同） } \\
\text { チームID非上昇群 }(\mathrm{N}=100 \text { 以下同 })\end{array}$ & $\begin{array}{l}4.17 \\
4.14\end{array}$ & $\begin{array}{l}0.89 \\
0.71\end{array}$ & $\begin{array}{l}4.00 \\
4.26\end{array}$ & $\begin{array}{l}1.04 \\
0.76\end{array}$ & $\begin{array}{l}4.31 \\
4.02\end{array}$ & $\begin{array}{l}0.89 \\
0.53\end{array}$ & $3.29^{*}$ & 0.05 & 0.06 \\
\hline \multicolumn{10}{|l|}{ 町内会·地域組織 参加経験 } \\
\hline $\begin{array}{r}\text { 上昇群 } \\
\text { 非上昇群 }\end{array}$ & $\begin{array}{l}3.45 \\
3.37\end{array}$ & $\begin{array}{l}1.45 \\
1.74\end{array}$ & $\begin{array}{l}3.31 \\
3.41\end{array}$ & $\begin{array}{l}1.65 \\
1.66\end{array}$ & $\begin{array}{l}4.14 \\
3.08\end{array}$ & $\begin{array}{l}1.57 \\
1.66\end{array}$ & $3.30^{*}$ & 2.69 & 0.59 \\
\hline \multicolumn{10}{|l|}{ 町内会‧地域組織 参加意向 } \\
\hline $\begin{array}{r}\text { 上昇群 } \\
\text { 非上昇群 }\end{array}$ & $\begin{array}{l}3.66 \\
3.94 \\
\end{array}$ & $\begin{array}{l}1.45 \\
1.45\end{array}$ & $\begin{array}{l}4.00 \\
3.90\end{array}$ & $\begin{array}{l}1.34 \\
1.39\end{array}$ & $\begin{array}{l}4.45 \\
3.59\end{array}$ & $\begin{array}{l}1.40 \\
1.27 \\
\end{array}$ & $4.14^{*}$ & 1.69 & 0.63 \\
\hline \multicolumn{10}{|l|}{ ボランティア活動 参加経験 } \\
\hline $\begin{array}{r}\text { 上昇群 } \\
\text { 非上昇群 }\end{array}$ & $\begin{array}{l}3.28 \\
3.11\end{array}$ & $\begin{array}{l}1.44 \\
1.66\end{array}$ & $\begin{array}{l}3.07 \\
3.15\end{array}$ & $\begin{array}{l}1.58 \\
1.54\end{array}$ & $\begin{array}{l}3.52 \\
2.90\end{array}$ & $\begin{array}{l}1.55 \\
1.62\end{array}$ & 1.17 & 1.34 & 0.11 \\
\hline \multicolumn{10}{|l|}{ ボランティア活動 参加意向 } \\
\hline $\begin{array}{r}\text { 上昇群 } \\
\text { 非上昇群 }\end{array}$ & $\begin{array}{l}3.59 \\
3.89\end{array}$ & $\begin{array}{l}1.30 \\
1.47\end{array}$ & $\begin{array}{l}3.76 \\
3.96\end{array}$ & $\begin{array}{l}1.53 \\
1.31 \\
\end{array}$ & $\begin{array}{l}4.34 \\
3.60\end{array}$ & $\begin{array}{l}1.37 \\
1.28 \\
\end{array}$ & $4.25^{*}$ & 0.21 & 0.70 \\
\hline \multicolumn{10}{|l|}{ 行事・イベント 参加経験 } \\
\hline $\begin{array}{r}\text { 上昇群 } \\
\text { 非上昇群 }\end{array}$ & $\begin{array}{l}3.38 \\
3.34 \\
\end{array}$ & $\begin{array}{l}1.57 \\
1.56\end{array}$ & $\begin{array}{l}3.07 \\
3.49 \\
\end{array}$ & $\begin{array}{l}1.39 \\
1.49 \\
\end{array}$ & $\begin{array}{l}3.76 \\
3.29\end{array}$ & $\begin{array}{l}1.41 \\
1.42 \\
\end{array}$ & 2.13 & 0.02 & 0.67 \\
\hline \multicolumn{10}{|l|}{ 行事・イベント 参加意向 } \\
\hline $\begin{array}{r}\text { 上昇群 } \\
\text { 非上昇群 }\end{array}$ & $\begin{array}{l}3.69 \\
3.93 \\
\end{array}$ & $\begin{array}{l}1.42 \\
1.42 \\
\end{array}$ & $\begin{array}{l}3.83 \\
4.13 \\
\end{array}$ & $\begin{array}{l}1.31 \\
1.27 \\
\end{array}$ & $\begin{array}{l}4.38 \\
3.79 \\
\end{array}$ & $\begin{array}{l}1.27 \\
1.28 \\
\end{array}$ & $3.06^{*}$ & 0.01 & 0.95 \\
\hline
\end{tabular}

が交互作用効果 $(\mathrm{F}(1,127)=3.30 p<.05)$ が 有意水準を満たし,「チームID上昇群」が高い 值を示した. 主効果は同水準を満たさなかった. 「ボランティア活動」と「イベント」は交互作 用効果, 主効果ともに有意水準を満たさなかっ た。

地域活動への参加意向は, 「町内会や地域 組織」の交互作用効果 $(\mathrm{F}(1,127)=4.14 p<$ .05),「ボランティア活動」の交互作用効果 ( F (1, 127) $=4.25 p<.05)$, 「行事・イベントの参加意 向」の交互作用効果 $(\mathrm{F}(1,127)=3.06 p<.05)$ が有意水準を満たし，いずれも「チームID上 昇群」が高い值を示した。主効果はチームID, 期間推移いずれも有意水準を満たさなかった。

さらに, 両群の社会的評価の比較（ $\mathrm{t}$ 検定） の結果, 全項目平均值 $(\mathrm{t}(127)=3.46 p<.001)$, 「日頃, 地域の人々と交流を持つことが多い」 $(\mathrm{t}(127)=3.39 p<.001)$, 「日頃, 地域の人々
と一緒に活動することが多い」（ t $(127)=3.17$ $p<.01)$, 「毎年, この地域で行われる祭りや イベントを楽しみにしている」（t (127) = 3.43 $p<.001)$, 「この地域には生活面で協力し合え

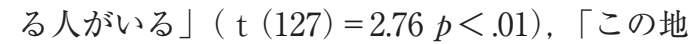
域の治安は良い」（t (127) = $1.99 p<.05 ）$ を示 し, 全項目平均值およびすべての項目で「チー ムID 上昇群」が有意に高い值を示した（表 7 ）。

\section{5. 考}

察

予備調査において物理的評価と社会的評価が 地域愛着に及ぼす影響の有無を検証した結果, 2 回の調查ともに, 社会的評価と物理的評価は 地域愛着に正の影響を及ぼし，かつ社会的評価 がより高い影響力を持つことが明らかになっ た。このことから，地域愛着影響構造は今治市 にも適合することが明らかとなった。なお，約 8 ケ月間をおいた 2 回の調查結果を比較する 
表 7 「チームID 上昇群」「非上昇群」の社会的評価の比較

\begin{tabular}{|c|c|c|c|c|c|}
\hline & M & $\mathrm{SD}$ & 自由度 & $\mathrm{t}$ 值 & \\
\hline \multicolumn{6}{|l|}{ 全項目平均 } \\
\hline チームID 上昇群（N=29 以下同） & 5.15 & 1.35 & \multirow{2}{*}{127} & \multirow{2}{*}{3.46} & \multirow{2}{*}{$* * *$} \\
\hline チームID非上昇群（N=100 以下同） & 4.15 & 1.37 & & & \\
\hline \multicolumn{6}{|l|}{ 日頃，地域の人々と交流を持つことが多い } \\
\hline 上昇群 & 5.34 & 1.54 & \multirow{2}{*}{127} & \multirow{2}{*}{3.39} & \multirow{2}{*}{$* * *$} \\
\hline 非上昇群 & 4.17 & 1.67 & & & \\
\hline \multicolumn{6}{|l|}{ 日頃, 地域の人々と一緒に活動する機会が多い } \\
\hline 上昇群 & 5.17 & 1.61 & \multirow{2}{*}{127} & \multirow{2}{*}{3.17} & \multirow{2}{*}{ ** } \\
\hline 非上昇群 & 4.02 & 1.76 & & & \\
\hline \multicolumn{6}{|c|}{ 毎年, この地域で行われる祭りやイベントを楽しみにしている } \\
\hline 上昇群 & 5.07 & 1.39 & \multirow{2}{*}{127} & \multirow{2}{*}{3.43} & \multirow{2}{*}{ *** } \\
\hline 非上昇群 & 3.91 & 1.66 & & & \\
\hline \multicolumn{6}{|l|}{ この地域には, 生活面で協力し合える人がいる } \\
\hline 上昇群 & 5.14 & 1.33 & \multirow{2}{*}{127} & \multirow{2}{*}{2.76} & \multirow{2}{*}{$* *$} \\
\hline 非上昇群 & 4.22 & 1.64 & & & \\
\hline \multicolumn{6}{|l|}{ この地域の治安は良い } \\
\hline 上昇群 & 5.03 & 1.48 & \multirow{2}{*}{127} & \multirow{2}{*}{1.99} & \multirow[t]{2}{*}{$*$} \\
\hline 非上昇群 & 4.45 & 1.37 & & & \\
\hline
\end{tabular}

と, 地域愛着は有意な変化は認められなかった. 地域愛着の醸成には一定の期間が必要とされ $る^{28)}$ ことから, 今治市も他地域と異なる特異性 は無く, 比較的短期間では地域愛着は変化しな い地域と見なすことができる。

同様に物理的評価も有意な変化が認められな かった.これは評価対象の「街並み」「自然」「建 造物」名産品」が物理的な存在であるがゆえに, 約 8 ケ月の間に状態に顕著な変化は生じず, 評 価が不変であったと考えられる.

一方で, 社会的評価が有意に低下した点は注 目される. その要因を探究することは本研究の 領域をこえるものであるが, 近所づきあいの減 少や孤独感の増加などは指摘されており ${ }^{29)}$, 今 治市も同様の傾向にあることが推察される. 地 域愛着影響構造に従えば, 社会的評価の低下は 地域愛着の低下を導くと考えられる。地域愛着 を維持ないしは上昇に導くには, 社会的評価を 高めるような何らかの事象・経験が必要とされ ることは認識しておく必要があろう.
仮説の検証の結果, まず地域愛着に関して, 「チームID上昇群」は期間の推移を伴いながら 「非上昇群」よりも有意に高い地域愛着の值を 示した. 菅ら ${ }^{13)}$ は 2 回の縦断的調査でこの結果 を導き出したが, 本研究ではさらに 1 回の調査 を加えた計 3 回の調査からも同様の結果を得た ことで, チームIDの上昇は地域愛着の上昇を 伴うことが改めて示されたといえる.

「地域社会との結びつき」の項目に関しては,

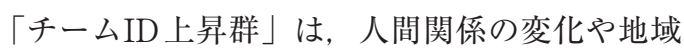
活動への参加意向の值を有意に上昇させ，その 鲕結として社会的評価も有意に高いことが明ら かになった。「地域愛着影響構造」が今治市に も適合することをふまえると，「チームIDの上 昇は, 社会的評価の上昇を伴い, 地域愛着の上 昇を導く」とする仮説は支持されたとするのが 妥当である.

「チームID上昇群」が「人間関係の変化」 の值を上昇させた背景には, 調査実施期間に, 町内や職場など身近な人間関係の中で FC 今治 
という共通の話題が喚起されたことや, FC今 治が主体の行事やイベントへの参加等により, 旧来の人間関係の強化や新たな人間関係の構築 が生じたことが推察される.

地域活動への参加意向に関しても,「チーム ID 上昇群」の上昇が目立った。近隣でのつき あいや社会的な交流と地域活動への参加は, 相 互に高まる関係が示されている ${ }^{30)}$ 。この点をふ まえると，「チームID上昇群」は人間関係が豊 かに変化したことに伴い, 地域活動への参加意 向も高めたことが考えられる。そうした中で, 「町内会や地域組織」は参加機会の頻度がボラ ンティア活動や行事・イベントに比べて一般的 に高いことから, 調查実施期間内にも実際の参 加経験回数が増えたと思われる.

III 期の調查時点での社会的評価を比較した結 果,「チームID 上昇群」が「非上昇群」よりも 高い結果を得た。この点に関して,「チームID 上昇群」の社会的評価は元々高かったとの解釈 も可能である. しかし, 予備調査において社会 的評価が約 8 力月間で有意に低下したことか ら, 今治市では何らかの事象・経験が生じない 状態では, 人間関係の希薄化などにより社会的 評価が緩やかに低下する状態にあるとも考えら れる。そうした中で，「チームID上昇群」は人 間関係や地域活動への参加意向など「地域社会 との結びつき」や社会的評価をむしろ上昇させ ている点は注目に值する。同群の社会的評価の 元々の高さを考慮したうえでも，チームIDの 上昇が社会的評価の上昇をもたらしたとする見 方はできるであろう。

今治市において「FC今治」に対する住民の 認知や関心は今後の増加が見込まれることか ら，住民のチームIDは「上昇の黎明期」にあ るといえる。そうした時期では，チームIDが 「直接的に」地域愛着の上昇を導くというより も, 社会的評価が媒介変数の役割を果たし,「間 接的に」地域愛着が上昇すると解釈できる。プ ロスポーツ振興を志向する地方自治体におい て, 地域愛着の醸成を政策上の KPIに定める際 には, 試合当日のスタジアムやアリーナの満員
を目指すだけではなく, 試合開催日以外の平常 時に拈いて，地域の人間関係を豊かに変化させ る方向性の中でチームを活用する視点が求めら れよう。例えば観戦者・ファン同士の交流機会 を拡げる行事・イベントの開催, チームとの連 携による町内会や地元企業の構成員・従業員の 横のつながりの強化, チームに由来する地域組 織（NPOなど）の設立によるボランティア活 動の促進などが想定される.

また，本調査の結果からチームID と期間推 移の交互作用効果のみが有意水準を満たしたこ とは，チームと地域のあり方を示している，有 意水準を満たした背景として,「チームID 上昇 群」が該当する項目の值を上昇させたことに加 えて，「非上昇群」が同值を低下させたことも 要因として指摘できる。換言すれば，プロス ポーツチームと地域の良好な関係が長期間にわ たり継続されてはじめて, 社会的評価の上昇が 伴い, 地域愛着の上昇が導かれる点は重要な示 唆といえる。

本研究では, チームIDの上昇は社会的評価 の上昇を伴い，地域愛着の上昇を導く構造が明 らかとされたが，予備調查で採用した「地域環 境に対する評価」尺度や, 本調査におけるチー ムIDや地域愛着の尺度の信頼性及び妥当性に 関して，基準を満たさない数值も一部算出され たことから検討の余地があり, 項目の削除や追 加も含めた課題が残された。

また，チームIDの上昇が社会的評価の上昇 を伴う点に関して,「チームID上昇群」の中で チームIDとは全く無関係な要因で社会的評価 を上昇させた回答者が含まれる可能性は, 群分 けによる分析を行ったものの完全には排除でき ない.この点については, 実際の回答者に対す るインタビューなど定性調査を通じて, 人間関 係の具体的な变化や地域活動への参加意向が高 まった背景等を把握する必要があると考えられ る.

\section{参 考 文 献}

1) 日本プロサッカーリーグ，Jリーグ25周年記 
念特設サイト https：//www. jleague. jp/ special/anniversary/25th/.

2) 石坂圭三, 間野義之; プロスポーツの地域に おける経済的価值評価, スポーツ産業学研究, Vol.20, No.2, pp.159-171, 2010.

3 ) 国土庁・日本システム研究所, スポーツを核と した地域活性化に関する調査ースポーツフロ ンティア $21,1995$.

4 ) 原田宗彦; スポーツビジネスの発展, 山下秋二, 原田宗彦編著：眓解スポーツマネジメント, 大 修館書店, pp.56-67, 2005.

5 ) 株式会社日本経済研究所, J クラブの存在が地 域にもたらす効果に関する調査, 2009.

6 ) Crompton, Beyond Economic Impact: An Alternative Rationale for the Public Subsidy of Major League Sports Facilities, Journal of Sport Management, Vol.18, pp.40-58, 2004.

7 ) Taks, Social sustainability of non-mega sport events in a global world, European Journal for Sport and Society, Vol.10, pp.121-141, 2013.

8 ) 山口志郎, 他 ; スポーツイベントが開催地域に もたらす効果: 先行研究の検討, 体育学研究, 2018. 早期公開.

9) 押見大地, スポーツイベントにおける包括的 社会効果尺度の開発, 笹川スポーツ研究助成, 2017.

10) Hogg, M.A., and Abrams, D. ; The social identity approach : Context and content. Social Identifications: A social psychology of intergroup relations and group processes, Routledge, pp.6-30, 1988.

11) Tajfel, H. and Turner, J.C. ; The social Identity Theory of Intergroup Behavior, Psychology of Intergroup Relations, Chicago : Nelson-Hall, pp. 7 -24, 1986.

12) Hidalgo, C., Hernandez B. ; Place attachment: Conceptual and Empirical Questions, Journal of Environmental Psychology, Vol.21, pp.273-281, 2001.

13）菅文彦, 他 ; チーム・アイデンティフィケー ションと地域愛着の因果関倸に関する考察— FC 今治の本拠地（愛媛県今治市）の住民を対 象としてー, スポーツ産業学研究, Vol.28, No.1, pp.1-11, 2018.
14) Lewicka, M. ; Ways to Make People Active : The Role of Place Attachment, Cultural Capital, and Neighborhood Ties, Journal of Environment Psychology, Vol.25, pp.381-395, 2005.

15）渡邊勉；地域に対する肯定観の規定因：愛着度, 住みやすさ，地域イメージに関する分析，地域 ブランド研究, No.2, pp.99-130, 2006.

16）鈴木春菜, 藤井聡;「消費行動」が「地域愛着」 に及ぼす影響に関する研究, 土木学会論文集 D, Vol.64, No.2, pp.190-200, 2008.

17）鈴木春菜, 藤井聡; 「地域風土」への移動途上 接触が「地域愛着」に及ぼす影響に関する研 究, 土木学会論文集 D, Vol.64, No.2, pp.179-189, 2008.

18）引地博之, 他 ; 地域に対する愛着の形成機構 一物理的環境と社会的環境の影響一, 土木学会 論文集 D, Vol.65, No.2, pp.101-110, 2009.

19) Putbnam, Bowling Alone: The Collapse and Revival of American Community, Simon \& Schuster, 2000.

20) Jarvie, G., Communitarianism, sport and social capital : Neighbourly insights into Scottish sport, International Review for the Sociology of Sport, Vol.38, No.2, pp.139-153, 2003.

21) Kay, T. and Bradbury, S., Youth sport volunteering : Developing social capital?, Sport Education and Society, Vol.14, No.1, pp.121-140, 2009.

22) Skinner, J., Zakus, D.H. and Cowell, J., Development through Sport: Building social capital in disadvantaged communities, Sport Management Review, Vol.11, No.3, pp.253-275, 2008.

23）長積仁, 他 ; 行為者間の信頼に基づく地域又 ポーツ振興事業の組織化と創発：ソーシャル・ キャピタルの機能と生成に着目して, 体育・又 ポーツ経営学研究, Vol.23, pp.11-31, 2009.

24）松野光範, 横山 勝彦 ; コミュニティ・ガバナ ンスによるまちづくり：昭和新山国際雪合戦 大会を事例に, 同志社政策科学研究, Vol.11, No.1, pp.49-60, 2009.

25）工藤康宏, 他 ; プロスポーツチームとまちづく りに関する研究ーチームと拠点地域住民の共 同参画型プロジェクトの開発と展開一, SSF ス ポーツ政策研究, Vol.3, No.1, 2013. 
26) Funk, D.C., and James, J.D. ; The Psychological Continuum Model: A conceptual framework for understanding an individual's psychological connection to sport. Sport Management Review, Vol.4, pp.119-150, 2001.

27）藤本淳也, 他; スポーツチームの地域転入と「ま ちづくり」の関連性, SSFスポーツ政策研究, Vol.3, No.1, 2014.
28）鈴木春菜, 藤井聡; 地域愛着が地域への協力行 動に及ぼす影響に関する研究, 土木計画学研 究・論文集, Vol.25, pp.357-362, 2008.

29）厚生労働省, 高齢社会白書, 2016.

30）内閣府経済社会総合研究所, コミュニティ機能 再生とソーシャル・キャピタルに関する研究 調査報告書, 2005 . 